\title{
Peertechz
}

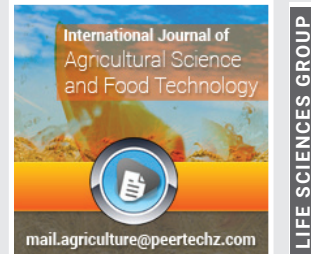

Review Article

\section{Review on Haploid and Double haploid Maize (Zea mays) breeding technology}

\section{Takele Mitiku*}

Ethiopian Institute of Agricultural Research, Ambo University, Department of Plant Science, Bako National Maize Research Center, Ethiopia
Received: 03 January, 2022

Accepted: 18 January, 2022

Published: 20 January, 2022

*Corresponding author: Takele Mitiku, Ethiopian Institute of Agricultural Research, Ambo University Department of Plant Science, Bako National Maize Research Center, P.O.BOX., 03, Ethiopia, Tel: +251923591600; Email: takelemitku202@gmail.com

ORCID: https://orcid.org/0000-0001-9136-2418

Keywords: Haploid; Double haploid; Maize; CrisprCas 9

Copyright License: ( 2022 Mitiku T. This is an openaccess article distributed under the terms of the Creative Commons Attribution License, which permits unrestricted use, distribution, and reproduction in any medium, provided the original author and source are credited.

https://www.peertechzpublications.com

\section{Check for updates}

\section{Abstract}

Maize (Zea mays L.) is a plant that is grown for human and animal consumption, as well as biofuel and a range of industrial applications throughout the world. By 2020 , it is predicted to outnumber wheat and rice in terms of demand. Farmers pick among two types of maize varieties in modern agriculture. Hybrids and open-pollinated varieties are mostly influenced by the current environmental and economic conditions and availability of seed for the preferred variety type. As a result, minimizing the time required for inbred development is critical in supplying varieties that fulfill the needs of modern farmers. The use of doubled haploid technology is the most effective way to accomplish this. The in vivo technique is widely regarded as a valuable tool for improving breeding efficiency. In maize, in vivo haploid induction has been quite successful and several commercial breeding programs currently use it extensively. Many factors such as anther stage, donor plant, and anther preparation were discovered to influence in vitro haploid induction (Androgenesis) in maize. Color indicators are widely used to distinguish typical fertilization kernels from those produced via haploid induction. Because gamete production is hindered in haploid plants, they are sterile. As a result, haploid chromosome duplication is required to permit self-pollination for seed production and genotype preservation. In the production of maize DH lines and colchicine is the most often used chemical as a chromosomal doubling agent. DHs are the ideal material for genetic improvement and genetic studies of maize because of their utility in homozygous line creation, recurrent selection, and induction of mutation, genetic enrichment, and compatibility with other technologies.

\section{Introduction}

Maize (Zea mays L.) is a plant that is grown for human and animal consumption, biofuel and a range of industrial uses applications all over the world. The crop, together with wheat (Triticum aestivum L.) and rice (Oryza sativa L.), is a dietary staple that feeds the majority of people in impoverished areas of Africa, Asia, and America with their primary source of calories [1]. By 2020, it is predicted to outnumber wheat and rice in terms of demand. This abrupt transition will result global maize demand will have increased by $50 \%$, from 558 million tons in 1995 to 837 million tons in 2020 [2]. Demand for maize for human consumption is expected to grow till the end of the year, at a rate of 1.3 percent every year 2020 in developing nations. Despite producing less than $8 \%$ of the world's total, globally, per capita consumption exceeds 127 million tons, with Africa accounting for nearly half of that for almost 30\% (FAOSTAT, 2015).

Resource-conserving farming techniques and enhanced crop varieties that produce more with the similar or less inputs than other crop variations now utilized are two significant instruments for satisfying maize and maize-based products will continue to be in high demand in the future. Farmers can choose between two sorts of maize cultivars in modern agriculture. Hybrids and open-pollinated types, and the factors that determine their selection is primarily influenced by the current environmental, economic conditions and availability of seed of the preferred variety type [3]. Crossing two homozygous inbred lines that are unrelated to create hybrid types is a regular practice.

From preliminary time to know human being try to

Citation: Mitiku T (2022) Review on Haploid and Double haploid Maize (Zea mays) breeding technology. J Agric Sc Food Technol 8(1): 052-058 DOI: https://dx.doi.org/10.17352/2455-815X.000145 
improve crop genetic variability and to fasten frequency of production. Converting conventional breeding into modern molecularly assisted breeding technique is one of main goal of breeders. To achieve this goal technique of haploid and double haploid is main strategy. To obtain sufficiently cross-breeding of maize plants, homozygous inbred lines tendency requires 6-10 generations of self-pollination, i.e. 3-5 years when two seasons per year may possible [4]. As a result, lowering the time required for inbred development is critical to increasing genetic benefits and accelerating the generation of superior varieties.

When haploid (n) cells successfully undergo chromosomal doubling, whether naturally or intentionally provoked, they generate a genotype known as a Double Haploid (DH). In comparison to the traditional inbred line creation technique, to get lines with 99 percent homozygozity, it requires at least 6-8 generations, the $\mathrm{DH}$ technology greatly reduces by swiftly establishing completely homozygous lines in 2-3 generations, the breeding cycle can be completed [5,6]. Plants (sporophytes) with a gametic chromosomal number are known as haploids (n). They can occur naturally or due to variety boosting approaches [7]. Blakeslee, et al. [8] were the first to report it in Datura stramonium; further reports in tobacco (Nicotiana tabacum), wheat (Triticum aestivum), and a variety of other species followed [9].

In maize, haploids can emerge naturally or owing to a variety of inductions approaches. However, because spontaneous occurrence is an uncommon occurrence, its practical relevance is restricted. As a result, many induction techniques have been researched and developed [10]. In vitro (androgenesis) or in vivo procedures can be used to generate haploids. Androgenesis is the process of anther or microspore culture producing haploid plants from immature pollen [11].

In vitro techniques have had limited success due to the nonresponsiveness of many maize genotypes, as well as the need for a competent laboratory and skilled workers. in vivo haploid induction-based DH line creation in maize, on the other hand, is relatively easier [12,13] with inducer genetic backgrounds integrating an anthocyanin color marker to permit easy identification of haploids at both the seed and seedling phases $[14,15]$.

The in vivo haploid induction-based $\mathrm{DH}$ method for maize breeding is widely recognized as a beneficial tool for increasing breeding efficiency. The method has been adopted by many commercial maize breeding projects in Europe [16]. The United States [17]. And China [18]. Improved inducer lines, more effective chromosome doubling methods, and protocols for rapidly introgression transgenes, notably stacked transgenes, are all being developed to make DHs more appealing [19].

However, in Latin America, Sub-Saharan Africa, and Asia are all home to tropical maize-growing countries, some public maize breeding organizations, and small and medium company seed enterprises, have fallen behind $[19,20]$. This could be due to a variety of factors, such as a lack of understanding of $\mathrm{DH}$ technology, a scarcity of tropicalized haploid inducers, or a lack of sufficient "know-how" for implementing DH into breeding programs. As a result, the purpose of this review is to look at where haploid and double haploid maize breeding is at the moment.

\section{Literature review}

\section{Haploid and double haploid breeding technology in maize}

Riley (1974) provided the first summary of haploid production, reporting that when A. D. Bergner found haploid in Datura stramonium in 1921, haploid production began. In Datura stramonium, this spontaneous generation of haploid plants has been described by [8]. Similar results have been recorded in crops such as tobacco (Nicotiana tabacum), wheat (Triticum aestivum), and a few more species [9]. In 1964, haploid embryo development from Datura anthers cultured In vitro revealed the promise of haploid for plant breeding [21].

Breeders/geneticists are encouraged to research alternative ways of haploid production in order to come up with a way to make haploids that are twice on a bigger scale due to the importance of haploid production [22]. Wide hybridization, parthenogenesis, foreign cytoplasm, pollen irradiation, and sparse pollination are some of the strategies that have been discovered as a result of these attempts [23].

Chase was the one who pioneered the use of haploid in maize breeding operations (1952). For the first time, he proposed DH-technology in maize based on maternal haploid inducers. It requires three steps: (I) producing haploid seeds using induction crosses; (ii) differentiating (iii) doubling the chromosomes of haploid plants; and (iv) haploid seeds from typical diploid crossing seeds [24].

\section{Haploid and double haploid production in maize}

The importance of haploids and DHs in breeding and genetics research was quickly recognized, and research into various methods and reasons for increasing haploid production frequency began. In maize breeding, several Haploid strategies for producing haploid and doubling haploids have been identified. Two gene sets are produced when haploid (n) cells undergo artificial or spontaneous chromosomal doubling so that are perfectly identical are resulting in a Doubled Haploid (DH) genotype [11]. DHs can be manufactured artificially using in vivo or In vitro procedures at varying frequencies, according to Barnabás, et al. [25] and Maluszynski, et al. [23].

Parthenogenesis and pseudogamy are the emphasis of the in vivo method. After that, the haploid embryo is rescued, cultivated, and chromosomally doubled to produce haploids with two chromosomes. Glycogenesis (ovary and flower culture) and oogenesis are the focus of the In vitro process. The multifactorial modulation of the In vitro androgenetic response is difficult according to genetic analyses conducted by numerous researchers. As a result, despite promising, the method has yielded promising results with select genotypes, it has yet to become a standard in maize breeding. in vivo techniques, on the other hand, have been widely used over the last two decades since they can be significantly enhanced. 
Four steps are normally produced DH lines: (I) By crossing heterozygous plants with a haploid inducer, haploids can be produced.; (ii) morphological markers for recognizing haploid kernels; (iii) chromosome doubling of haploids by colchicine treatment; and (iv) To obtain DH line seeds, selfing is used $[17,26]$.

In vitro methods consistently produce the large numbers of $\mathrm{DH}$ lines required by maize breeding programs, whereas in vivo haploid induction paved the way for large-scale DH line production, and in vivo haploid induction is now used in almost all DH production pipelines in multinational companies' maize breeding programs [11], (Liu, et al. 2016). Between the 1920s and 1960s, haploid maize plants were discovered in nature, but at a low frequency $(0.1 \%)$, laying the framework for in vivo $\mathrm{DH}$ creation [27]. Because this technique is less dependent on the donor genotypes from which $\mathrm{DH}$ lines are created, the discovery of Stock 6 [12]. And the development of a range of maternal haploid inducers in maize revolutionized the application of $\mathrm{DH}$ technology in maize breeding.

in vivo haploid induction can occur in two ways: haploids in both the maternal and paternal lines $[28,29]$. In vivo induction of maternal haploids is the most common induction approach for maize (Zea mays L.). This method relies on the employment of specific genotypes with the ability to produce haploids. The processes of maternal haploid induction have been the subject of two hypotheses. Wedzony [30] proposes the first hypothesis, which claims that one of the two sperm cells in the inducer line pollen is defective but still capable of fusing with the egg cell. The inducer parent's chromosomes degrade and are removed during cell division, from the primordial cells. Chalyk, et al. [31] propose a second hypothesis in which the egg cell and one of the two sperm cells are unable to fuse. As a result of this process, haploid embryogenesis is triggered. After that, the second sperm cell joins the center cell. The haploids that result are tiny, have limited plant vigor, and are sterile. Their fertility must be restored in order for them to reproduce. This can be achieved through either spontaneous or induced chromosomal doubling. The doubled haploids (DH) that result are fully homozygous and homogenous [31] Figure 1.

Various international institutions developed public inducer genotypes for maternal haploids, which encompass a wide range of HIR, including $2 \%$ for Stock6 [12]. The first germplasm to induce haploidy and the ancestor of all modern inducers, and $8 \%-10 \%$ for RWS [28]. HZI [29]. And PHI [29,33].
Maize haploids can be obtained using In vitro fertilization (androgenesis). The technique of producing haploid plants from immature pollen using either Anther or Microspore culture is known as androgenesis [11]. Androgenesis is induced in microspores within the anther culture systems, resulting in microspore-derived embryo-like structures. Embryo-like structures can regenerate either directly into haploid plants or indirectly as regenerable calli. Microspores are relatively straightforward to access and control in cultures because they are abundant in plant anthers. In maize, obtaining haploids and DH by androgenesis has not proven to be effective, despite the fact that androgenesis techniques are well known and commonly utilized in some crop species. Androgenesis in maize has been discovered to most maize genotypes are genotype dependent resistant to culture and show no response [34,35]. Even in various factors such as anther stage, donor plant, and anther pretreatment, genotypes respond to androgenesis [3436].

Color markers are often used by maize breeders to separate between kernels created by ordinary fertilization and those produced via haploid induction. Different ways for distinguishing haploid from diploid kernels have been discovered [37]. Chase [27]. Developed a phenotypic marker system based on the R1 locus's dominant variation allele R1nj (R1-navajo), which codes for anthocyanin coloration. The inclusion of anthocyanin markers in haploid inducer lines allows for easier haploid identification at the seed level and at various stages of plant development. In the presence of the dominant pigmentation genes $\mathrm{A} 1, \mathrm{~A} 2$, and $\mathrm{C} 2, \mathrm{R} 1-\mathrm{nj}$ induces high pigmentation of the aleurone layer (endosperm tissue) in the crown and scutellum (embryo tissue) of the kernel. The degree and intensity of pigmentation change based on the donor genotype's genetic background [38].

According to Greenblatt and Bock [15]. Experiment red crown mutant was initially used as a selective flag in haploid induction. They discovered that the donor parent must contain the inducer line of homozygous for R1-nj and dominant pigmentation genes, and the seeds must be colorless. to be successful. The use of haploid inducers with anthocyanin genes $\mathrm{B} 1$ (Booster1) and $\mathrm{Pl} 1$ (Purple1) that result in sunlightindependent purple coloration in plant tissue (coleoptiles and root) has been proven to be appropriate in situations where haploid sorting is not possible at the dry seed stage [33]. Pigmented coleoptiles or roots in this example indicate a diploid state in the early stages of development, whereas nonpigmented seedlings could be categorized as haploids [33,38].

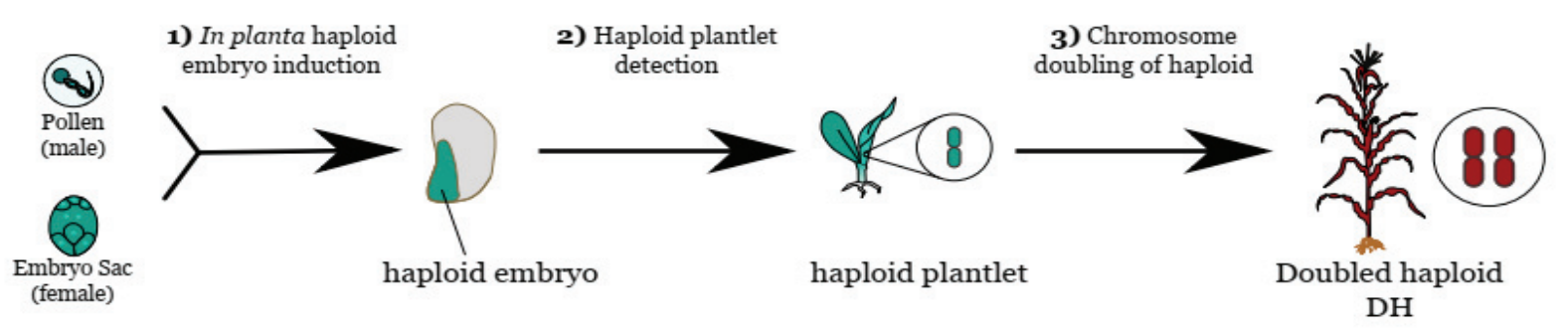

Citation: Mitiku T (2022) Review on Haploid and Double haploid Maize (Zea mays) breeding technology. J Agric Sc Food Technol 8(1): 052-058. DOI: https://dx.doi.org/10.17352/2455-815X.000145 




Figure 2: Shows over all steps of haploid and double haploid. Source: Nathanaël J, et al. 2021 [32].

The root color marker and the R1-nj gene have been used in a few backcross populations at CIMMYT, but the HIR, agronomic stability, and efficacy of this alternative marker scheme in $\mathrm{DH}$ production must all be determined [11].

Furthermore, Rotarenco, et al. [39]. Proposed employing nuclear magnetic resonance to detect haploid kernels based on kernel oil content. $\mathrm{Li}$, et al. [40]. Created the inducer line CAUHOI, which permits haploids to be identified due to the lack of R1-nj-induced scutellum coloring as well as the low embryo oil content. To distinguish haploid maize kernels from hybrid maize kernels after maternal haploid induction, Jones, et al. [41]. Investigated the use of Near Infrared Reflectance (NIR) transmission spectroscopy. Growth traits such as upright leaves, weak vitality, and sterility distinguish haploid plants from diploid plants. Separating haploids from diploids at the seed level is crucial for commercializing DH technology because it reduces costs associated with chromosome doubling, green house, field space, and manpower [11].

Because of defective gamete production, the large percentage of haploid plants are infertile [42]. As a result, haploid chromosome duplication is required to permit seed production and genotype preservation through self-pollination. Colchicine is the most prevalent chromosomal doubling agent in maize. It prevents the production of microtubules and chromosome polar migration, resulting in single cells with tripled chromosomal numbers [43].

Deimling, et al. [44]. Devised protocols for treating colchicine, including germination of presumptive haploids at $26^{\circ} \mathrm{C}$ for three days, Seedlings are prepared by reducing the root and trimming the tip coleoptiles, then immersed in a Colchicine solution (0.06 percent colchicine, 0.5 percent dimethyl sulfoxide) at room temperature for 12 hours in a dark room. After that, the treated plants are planted in the field [38].

For the in vivo generation of maize $\mathrm{DH}$ lines, several colchicine-based strategies for large-scale chromosomal duplication have been devised [44]. And In vitro [25,43]. Another option is to use nitrous oxide to treat haploids or herbicides with anti-microtubule properties [36] Figure 2.

\section{Gen editing crispr-cas9 technology}

At recent times, remarkable result have achieved by breeders using molecular technology. Clustered Regularly Interspaced 
Short Palindromic Repeats (CRISPR)/Cas9 technology is a new gene-editing system, succeeded in improving crop quality [45]. In relative to TALENS, ZFNs, and MNs it is simple, efficient, and cost-effective technique to edit multiple genomes at the same time [46,47]. GE-mediated DNA modifications through (CRISPR)/Cas9 encompass deletions, insertions, Single Nucleotide Substitution (SNPs), and large fragment substitution. The plant CRISPR/Cas9 and its derived system have shown various genome-editing ability, such as gene knock-in, knockout, knockdown, and expression activation as well. The following step is the work flow of CRISPR/Cas9based gene editing.

Select genes of interest for editing and design spacers for selected genes $\rightarrow$ Prepare transformation carrier or Ribonucleoprotein (RNP) $\rightarrow$ Deliver foreign nucleotides or proteins into plant cells $\rightarrow$ Identify edited lines in To generation by NGS $\rightarrow$ Select null plants with the gene edited in T1 and confirm them by NGS in T2 generation $\rightarrow$ Obtain homozygous edited lines and the evaluation of expression of the target gene $\rightarrow$ use of the null lines for breeding new variety [48].

\section{Applications of haploid and doubled haploids bree- ding technology in maize}

In comparison to traditional procedures, to get a partly homozygous plant, it takes generations of self-pollination, $\mathrm{DH}$ technology allows entirely homozygous plants to be obtained in two generations $[17,26,28,33]$. DH lines are completely homozygous and homogeneous, making them good candidates for plant variety protection According to Rober, et al. [28]. They also showed that using DH lines enables for commercialization to begin many seasons earlier than with traditional breeding.

Recurrent Selection (RS) is an important component in hybrid breeding [49]. Best line selection can be isolated and used to create hybrids that are superior from prior rounds [50]. The goal of recurrent selection in hybrid breeding is to enhance a heterotic group's General Combining Ability (GCA) in comparison to other groups, referred to as the "opposite" pool (s). Recurrent selection based on Doubled Haploid (DH) lines can be quite efficient in this regard. Using DH lines has several advantages, including a maximum genetic variance across test units and improved precision in evaluating the genotypic value of DH lines and their testcrosses [28]. Due to recombination and selection, doubled haploids can be used in a recurrent selection system, in which the population is projected to improve after repeated cycles of crossing, DH generation, and selection [51,52]. (Gordillo, et al. 2010).

Another application of DH technology is mutation breeding. Homozygosity allows fixing of mutations in the first generation [7]. Pure haploid plants, as an alternative to DH technology, can be employed for breeding and research. This is due to their ability to produce normal kernels after pollination with diploid pollen (Rotarenco, et al. 2012) [53]. In microspore cultivation, treating microspores with chemical mutagenesis during the uninucleate stage is a particularly effective way to create mutants, resulting in pure elite mutant inbred lines [54].

Recycling $\mathrm{DH}$ lines has been demonstrated to fast increase haploid frequency and restore fertility [55,56]. Chase [55]. Discovered that the stiff stalk synthetic materials produced 0.13 percent haploids, whereas the haploid derived DHs produced 0.43 percent haploids. The original stiff stalk synthetic had a 9.4 percent haploid fertility restoration, and the frequency of DH derived haploids climbed to 33 percent. Selection appears to favor genetic or germplasm enrichment for the generation of haploids and fertility restoration. Using random mating of high yielding DH lines as a source of resources for the next haploid selection cycle, maize plant germplasm enrichment for yield, general vigor, and agronomy can be done. Recurrent selection or any other breeding plan can be used to enrich inbred lines with more favorable alleles for yield, insect resistance, stress tolerance, and other agronomic attributes [51,53].

DH and molecular markers have emerged as two of the most powerful tools in applied maize breeding projects in recent years, changing how homozygous lines are formed [57]. DH technology can be used with marker assisted selection in maize breeding (MAS). The goal of combining MAS and DNA fingerprinting with DHs is to: (1) select parents with complementary genotypes to form crosses for use in generating DH lines; and (2) select parents with complementary genotypes to form crosses for use in generating DH lines [19]. It's possible to use MAS and DHs in repeating selection activities. Bouchez and Gallais [51]. Used simulations to show that employing DH lines to pick parents for following cycles of recurrent selection projects improves the efficiency of recurrent selection methods for low heritability variables. MAS may be less expensive, faster, or more effective than phenotyping DH lines to choose parents for successive recurrent selection projects cycles.

Another way that DH and MAS collaborate is to generate DH lines from bi-parental crossings with the goal of obtaining inbred lines that are genetically identical to either parent of the cross $[58,59]$. Or finding recombinants at or flanking specified loci. Finally, the most common combined usage of DH and MAS is expected to be genetic research such as bulked segregant analysis and constructing genetic maps $[5,6]$.

\section{Conclusion and summary}

Maize is the top three cereals for global food security significantly in Africa and Latin America. It is demanded for food, feed, fuel, and industrial purposes over the world. Adopting DH technology in maize breeding is urgently needed to meet the expanding demand for maize products. In comparison to the traditional inbred line creation technique, the DH technology greatly reduces the breeding round by rapidly developing entirely genetically homozygous inbred lines in 2-3 generations. When haploid (n) cells undergo artificial or spontaneous chromosome doubling, they create two gene sets that are $100 \%$ identical. Artificially produced DHs can be made using in vivo or In vitro procedures. The in vivo haploid induction-based DH method for maize breeding is widely recognized as a beneficial tool for increasing breeding efficiency.

There are four steps in the DH line. The production method includes processes such as inducing haploids by crossing

Citation: Mitiku T (2022) Review on Haploid and Double haploid Maize (Zea mays) breeding technology. J Agric Sc Food Technol 8(1): 052-058. 
heterozygous plants with a haploid inducer, detecting haploid kernels, chromosome doubling of haploids, and selfing to obtain seeds of DH lines. The use of DHs in maize breeding is extremely essential. DHs are the ideal material for genetic improvement and genetic studies of maize because of their utility in homozygous line creation, recurrent selection, and induction of mutation, genetic enrichment, and compatibility with other technologies.

\section{References}

1. Dowswell CR, Paliwal RL, Cantrell RP (1996) Maize in the third world Westview Press, Inc. Colorado, USA. Link: https://bit.ly/3nEp6Go

2. Pingali PL, Pandey S (2001) Meeting world maize needs: technological opportunities and priorities for the public sector. In: Pingali, P.L. (ed.) 2001. CIMMYT 1999-2000 World Maize Facts and Trends. Meeting World Maize Needs: Technological Opportunities and Priorities for The Public Sector. Link: https://bit.ly/32gwFvw

3. Pixley KV, B"anziger M (2004) Open-pollinated maize varieties: A backward step or valuable option for farmers? p. 22-29. In: Friesen DK, Palmer AEF (eds.) Integrated approaches to higher maize productivity in the new millennium. Proc. Of the 7th Eastern and Southern Africa Regional Maize Conf, Nairobi, Kenya. 5-11.

4. Hallauer AR, Carena MJ, Miranda Filho JB (2010) Quantitative Genetics in Maize Breeding. Springer Science and Business Media, New York. Link: https://bit.ly/3GIJygV

5. Foster BP, Thomas WTB (2005) Doubled haploids in genetics and plant breeding. In J Janick (ed) plant breed Rev 25: 57-88. Link: https://bit.ly/3tK68BY

6. Chang, MT, Coe EH (2009) Biotechnology in agriculture and forestry. vol. 63 Molecular genetic approachs to maize improvent. Springer Verlag, Berlin, Heidelberg 127-142.

7. Murovec, J, Bohanec B (2012) Haploids and Doubled Haploids in Plant Breeding. Plant Breeding Dr. Ibrokhim Abdurakhmonov (Ed.). Link: https://bit.ly/3fHCJAg

8. Blakeslee, AF, Belling J, Farnham ME, Bergner AD (1922) A haploid mutant in the Jimson weed, Datura stramonium. Science. 55 : 646-647. Link: https://bit.ly/3AeTqMX

9. Forster BP, Heberle-Bors E, Kasha K, Touraev A (2007) The resurgence of haploids in higher plants. Trends Plant Sci 12: 368-375. Link: https://bit.ly/3nGuN6P

10. Mureseanu SG, Dicu G, Marin DI, Rotarenco V (2013) Haploid in maize (zea mays L.) breeding and research. Scientific Papers Series A Agronomy 56: 314-318. Link: https://bit.ly/3tFUqsb

11. Prasanna BM, Chaikam V, Mahuku G (2012) Doubled haploid Technology in Maize Breeding: Theory and Practice. Mexico, D.F CIMMYT. Link: https://bit.ly/3flpYoW

12. Coe EH (1959) A line of maize with high haploid frequency. American Naturalist 93: 381-382. Link: https://bit.ly/3AflcaN

13. Coe EH, Sarkar KR (1964) The detection of haploids in maize.J Heredity 55: 231-233. Link: https://bit.ly/33L9ud3

14. Nanda DK, Chase SS (1966) An embryo marker for detecting monoploids of maize (Zea mays L.). Crop Sci 6: 213-215. Link: https://bit.ly/3rAfuxC

15. Greenblatt I.M, Bock M (1967) A commercially desirable procedure for detection of monoploids in maize. J Heredity 58: 9-13. Link: https://bit.ly/3GPZHRB

16. Schmidt W (2003) Hybrid maize breeding at the KWS SAAT AG. In: Workshop of the Association of Seed Breeding Director in Gump Einstein 1-6.

17. Seitz $G$ (2005) The use of double haploids in corn breeding. In. Proceedings of the forty first annual Illinois Corn Breeders' School 2005, Urbana-Campaign, Illinois USA 1-7.
18. Chen S, Li L, Li H (2009) Maize Doubled Haploid Breeding. China Agricultural University Press, Beijing.

19. Prasanna BM, Pixley K, Warburton ML, Xie CX (2010) Molecular markerassisted breeding options for maize improvement in Asia. Molecular Breeding 26: 339-356. Link: https://bit.ly/3qJovFp

20. Kebede AZ, Dhillon BS, Schipprack W, Araus JL, Bänziger M, et al. (2011) Effect of source germplasm and season on the in vivo haploid induction rate in tropical maize. Eupytica 180: 219-226. Link: https://bit.ly/33R6w6G

21. Guha S, Mahesh Wari SC (1964) In vitro Production of Embryos from Anthers of Datura. Nature 204: 497. Link: https://go.nature.com/3AjnZkr

22. Kimber G, Riley R (1963) Haploid angiosperms. Bot Rev 29: 480-531. Link: https://bit.ly/3rBCxYD

23. Maluszynski M, Kasha KJ, Forster BP, Szarejko I (2003) Doubled haploid production in crop plants- A Manual. Kluwer Academic Publ. The Netherlands ISBN 1-4020-1544-5.

24. Prigge V, Sanchez BSD, Schipprack W, Araus JL, Bänziger M, et al. (2011) Doubled haploids in tropical maize: I. Effects of inducers and source germplasm on in vivo haploid induction rates. Crop Sci 51: 1498-1506. Link: https://bit.ly/3nGrCff

25. Barnabas B, Obert B, Kovacs G (1999) Colchicine, an efficient genomedoubling agent for maize (Zea mays L.) microspores cultured in anthers. Plant Cell Reports 18: 858-862. Link: https://bit.ly/3KqnfyE

26. Melchinger AE, Longin CF, Utz HF, Reif JC (2005) Hybrid maize breeding with double haploids lines: quantitative genetic and selection theory for optimum allocation of resources. In Proc. 41st Annu. Illinois Corn Breeders School.7-8.

27. Chase SS (1969) Monoploids and monoploid derivatives of maize (Zea mays L.). Botanical Review.35: 117-167. Link: https://bit.ly/3tGXwfr

28. Rober FK, Gordillo GA, Geiger HH (2005) In vivo haploid induction in maizePerformance of new inducers and significance of doubled haploid lines in hybrid breeding. Maydica 50: 275-283. Link: https://bit.ly/3lkDr2x

29. Zhang ZL, Qiu FZ, Liu YZ, Ma KJZ, Li Y (2008) Chromosome elimination and in vivo haploid induction by stock 6 - derived inducer line in maize (Zea mays $L$.). Plant Cell Reports 27: 1851-1860.Link: https://bit.ly/3rxDHVg

30. Wedzony M, R" ober F, Geiger HH (2002) Chromosome elimination observed in selfed progenies of maize inducer line RWS. In: VII Intern. Congress on Sexual Plant Reproduction. Maria Curie-Sklodowska University Press, Lublin Poland 173 .

31. Chalyk S, Baumann A, Daniel G, Eder J (2003) Aneuploidy as a possible cause of haploid-induction in maize. Maize Genet News 77: 29-30.

32. Jacquier N, Gilles L, Martinant JP, Rogowsky P, Widiez T (2021) Maize In Planta Haploid Inducer Lines: A Cornerstone for Doubled Haploid Technology. Methods Mol Biol 2288: 25-48. Link: https://bit.ly/3nHwYqz

33. Rotarenco V, Dicu G, State D, Fuia S (2010) new inducers of maternal haploids in maize. Maize Genet Newsl 84: 15. Link: https://bit.ly/3rzHnpx

34. Genovesi AD, Collins GB (1982) In vitro production of haploid plants of corn via anther culture. Crop Sci 22: 1137-1144. Link: https://bit.ly/3FHdubK

35. Spitko T, Sagi L, Pintér J, Marton LC, Barnabas B (2006) Haploid regeneration aptitude of maize (Zea mays L.) - Lines of various origin and of their hybrids. Maydica 51: 537-542. Link: https://bit.ly/3nFezuy

36. Wan Y, Duncan DR, Raybun AL, Petolino JF, Widholm JM (1991) The use of ant microtubule herbicides for the production of doubled haploid plants from anther derived maize callus. Theory Apple Genet 81: 205-211. Link: https://bit.ly/3lfJDc8

37. Odiyo OA (2013) Performance of doubled haploid maize inbred lines in f1 hybrids under stress and non-stress conditions. MSc Thesis, Nairobi University. Nairobi, Kenya. Link: https://bit.ly/3FIpfP2

38. Geiger HH, Gordillo GA (2009) Doubled haploids in hybrid maize breeding Maydica 54: 485-499. Link: https://bit.ly/3AanCJ2

39. Rotarenco VA, Kirtoca IH, Jacota AG(2007) Possibility to identify kernels with haploid embryo by oil content. Maize Genetics Cooperation Newsletter 81: 11

Citation: Mitiku T (2022) Review on Haploid and Double haploid Maize (Zea mays) breeding technology. J Agric Sc Food Technol 8(1): 052-058 DOI: https://dx.doi.org/10.17352/2455-815X.000145 
40. Li L, Xu X, Jin W, Chen S (2009) Morphological and molecular evidences for DNA introgression in haploid induction via a high oil inducer CAUHOI in maize. Planta 230: 367-376. Link: https://bit.ly/34UmE84

41. Jones RW, Reinot T, Frei UK, Tseng Y, Lubberstedt T, et al. (2012) Selection of haploid maize kernels from hybrid kernels for plant breeding using NearInfrared Spectoscopy and SIMCA analysis. Appl Spectrosc 66: 447-450. Link: https://bit.ly/3tG8YrR

42. Tang QL, Feng YC, Han XL, Zheng MM, Rong TZ (2009) Study on haploid inducing and its meiotic abnormality in maize. Agricultural Sciences in China 8: 1159-1165. Link: https://bit.ly/3KpnIGD

43. Wan Y, Petolino J, Widholm J (1989) Efficient production of doubled haploid plants through colchicine treatment of anther-derived maize callus. Theor Appl Genet 77: 889-892. Link: https://bit.ly/3FJk9Cq

44. Deimling S, R"ober FK, Geiger HH (1997) Methodik und Genetik der in-vivoHaploideninduktion bei Mais. Vortr Pflanzenz"uchtg 38: 203-224.

45. Barone P, Wu E, Lenderts B, Anand A, Gordon-Kamm W, et al. (2020) Efficient Gene Targeting in Maize Using Inducible CRISPR-Cas9 and Marker-free Donor Template. Mol Plant 13: 1219-1227. Link: https://bit.ly/3IIBSRQ

46. Cong L, Ran FA, Cox D, Lin S, Barretto R, et al. (2013) Multiplex genome engineering using CRISPR/Cas systems. Science 339: 819-823. Link: https://bit.ly/3tGp58M

47. Mali P, Yang L, Esvelt KM, Aach J, Guell M, et al. (2013) RNA-guided human genome engineering via Cas9. Science 339: 823-826. Link: https://bit.ly/3KmXAXz

48. Liu Q, Yang F, Zhang J, Liu H, Rahman S, et al. (2021) Application of CRISPR / Cas9 in Crop Quality Improvement'. Int J Mol Sci 22: 4206. Link: https://bit.ly/33QJUDC

49. Hallauer AR, Miranda JB (1988) Quantitative genetics in maize breeding. 2nd ed. lowa State Univ. Press, Ames.
50. Suwantaradon K, Eberhart SA (1974) Developing hybrids from two improved maize populations. Theor Appl Genet 44: 206-210.

51. Bouchez A, Gallais A (2000) Efficiency of the use of doubled haploids in recurrent selection for combining ability. Crop Sci 40: 23-29. Link: https://bit.ly/3KrkH3q

52. Gallais A (2009) Full-sib reciprocal recurrent selection with the use of doubled haploids. Crop Sci 49: 150-152. Link: https://bit.ly/3AfYAlh

53. Chalyk ST, Rotarenco V (2001) The use of matroclinous maize haploid for recurrent selection. Russ J Genet 37: 1382-1387.

54. Szarejko I (2003) Doubled haploid mutation production. In: Maluszynsk M,Kasha KJ, Forster BP, Szarejko, I(eds) Doubled haploids production in crop plants, a manual. Kluwer, Dord-recht 106-112.

55. Chase SS (1952) Production of homozygous diploids of maize from monoploids. Agron J 44: 263-267. Link: https://bit.ly/3fIW6IY

56. Liu ZZ, Song TM (2000) Fertility spontaneously restoring of inflorescence and chromosome doubling by chemical treatment in maize haploid. Acta Agron Sin 26: 947-952. Link: https://bit.ly/3nE6HJG

57. Mayor P, Bernardo R (2009) Doubled haploids in commercial maize breeding one stage and two stage selection versus marker assisted recurrent selection. Maydica 54: 439-448. Link: https://bit.ly/3lzoXw7

58. Smith JSC, Hussain T, Jones ES, Graham G, Podlich D, et al. (2008) Use of doubled haploids in maize breeding: implications for intellectual property protection and genetic diversity in hybrid crops. Mol Breed 22: 51-59. Link: https://bit.ly/3fBI7WD

59. H ntzschel KR Weber G (2010) Blockage of mitosis in maize root tips using colchicine-alternatives. Protoplasma 241: 99-104. Link: https://bit.ly/3rwwlMb
Discover a bigger Impact and Visibility of your article publication with

Peertechz Publications
Highlights

* Signatory publisher of ORCID

* Signatory Publisher of DORA (San Francisco Declaration on Research Assessment)

* Articles archived in worlds' renowned service providers such as Portico, CNKI, AGRIS, TDNet, Base (Bielefeld University Library), CrossRef, Scilit, J-Gate etc.

* Journals indexed in ICMJE, SHERPA/ROMEO, Google Scholar etc.

* OAI-PMH (Open Archives Initiative Protocol for Metadata Harvesting)

* Dedicated Editorial Board for every journa

* Accurate and rapid peer-review process

* Increased citations of published articles through promotions

* Reduced timeline for article publication

Submit your articles and experience a new surge in publication services (https://www.peertechz.com/submission). 